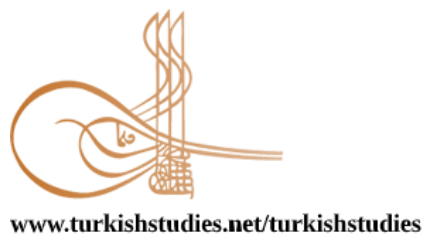

Turkish Studies

www.turkishstudies.net/turkishstudies

eISSN: $1308-2140$

BALKAN
UNIVERSTTY

Sponsored by IBU

Research Article / Araștırma Makalesi

\title{
COVID-19 Kaygısının Motivasyon Üzerindeki Etkisi: Z Kuşağı Üzerine Bir Araştırma
}

The Effect of COVID-19 Anxiety on Motivation: An Investigation on Generation Z

\author{
Erol Tekin*
}

\begin{abstract}
The effects of the COVID-19 pandemic are discussed in areas such as health and the economy, as well as in behavioral areas that consider human beings as a social entity. During this period, different processes experienced by individuals aged 65 and over, and young people have emerged. There exist measures and sanctions on the conscious actions of young people, especially the so-called Z-generation, on many issues, including "social distance". What effect this period had on young people is an issue wondered. The aim of this study is to reveals the effect of the anxiety caused by the COVID-19 pandemic on the motivation of Zgeneration. Within the scope of this aim, a questionnaire is applied to 398 students in different departments at Kastamonu University. In addition, the approval of the Ethics Committee dated 30.06.2020 and numbered 2020 /2-8 was obtained from the Social and Humanities Research and Publication Ethics Committee of Kastamonu University. The obtained data are tested by Confirmatory Factor Analysis, correlation analysis and regression analysis. As a result of the research, the socialization anxiety caused by the COVID-19 outbreak was found to be higher than the individual anxiety. Furthermore, it was determined that the socialization anxiety of Zgeneration affects both intrinsic and extrinsic motivation significantly and negatively. However, it has been found that individual anxiety does not have any effect on motivation. Since it is one of the first studies in the area, the study contributes to the literature on the Z-generation related to the COVID-19 pandemic.
\end{abstract}

Structured Abstract: Introduction. The COVID-19 pandemic has caused economic and sociological changes together with the health sector. Curfews and restrictions have been imposed in many countries during the pandemic. In Turkey, curfew restrictions have been imposed on people over the age of 65 and young people under the age of 20. There are studies investigating the effects of these restrictions on the economy and various sectors. However, the effects of the young people who are using the social environments very much by their ages and who are called Z-generation in a sudden transition to a different lifestyle, are particularly wondered. Therefore, it is important to put forward the concerns of these young people, who constitute approximately 17 percent of Turkey's population (Tekin and Zorkun, 2019), and reveal the implications posed by these concerns and anxieties in such a period. Because the decisions to be taken today about the young people who will shape the future will have great social impacts in the future. In addition, the effects of the epidemic need to be addressed not only in the health sector and in the economic context, but also in the behavioral aspect of the organizational behavior discipline, which demonstrates that human beings are a social entity. In this context, the purpose of the study is to examine the effect of COVID-19 anxiety levels on motivation in young people of Z-generation.

\footnotetext{
* Dr. Öğr. Üyesi, Kastamonu Üniversitesi, İktisadi ve İdari Bilimler Fakültesi, Uluslararası Ticaret ve Lojistik Bölümü Asst. Prof, Kastamonu University, Faculty of Economics and Administrative Sciences, International Trade and Logistics Department

ORCID 0000-0003-1166-7671

etekin@kastamonu.edu.tr
}

Cite as/ Atıf: Tekin, E. (2020). COVID-19 kaygısının motivasyon üzerindeki etkisi: Z Kuşağı üzerine bir araştırma. Turkish Studies, 15(4), 1129-1145. https://dx.doi.org/10.7827/TurkishStudies.44070

Received/Geliș: 06 June/Haziran 2020

Accepted/Kabul: 10 August/Ağustos 2020

Copyright $(\mathrm{C}$ MDE, Turkey
Checked by plagiarism software

Published/Yayın: 30 August/Ağustos 2020

CC BY-NC 4.0 
Method. The universe of the research is consist of students who are studying in different colleges and faculties of Kastamonu University and who attend the 2019-2020 Spring semester with distance education due to the COVID-19 pandemic and are in Z-generation. 411 students returned to the questionnaires sent via e-mail and social channels. Since they were incomplete, 13 of these forms were removed. Therefore 398 students formed the sample of the study. The data collection tool in the research is a questionnaire.

Findings and discussion. As a result of applied factor analyses, it was determined that COVID-19 anxiety was divided into two dimensions as individual anxiety and socialization anxiety, as in the original scale. No questions were removed from the COVID-19 scale, and the rate of disclosure was approximately $63 \%$. While the total reliability of the scale was at a high level of 0.906 , the reliability of the individual anxiety was found to be quite high at 0.929 for the sub-dimensions. The reliability of socialization anxiety was found to be high with 0.879 . As a result of the factor analysis, no questions were drawn from the original scale. The scale is divided into two dimensions, intrinsic and extrinsic motivation. As a result of the factor analysis, the total variance of the scale explained was approximately 57\%. The reliability of the intrinsic motivation among the scale dimensions was quite high with 0.942 . The reliability of the extrinsic motivation scale was also determined at a high level with 0.854 . The reliability of the entire scale was quite high with 0.928 .

COVID-19 appears to have a high level of anxiety (3.56). It was determined that socialization anxiety (3.79) ) was greater than individual anxiety (3.33). When the motivation levels of the participants were analyzed, it was found to be at low levels (2.80). It can be seen as a result of the analysis that the intrinsic motivation (2.73) in the sub-dimensions is lower than the extrinsic motivation (2.88). Socialization anxiety affects motivation significantly and negatively as it was determined as a result of regression analysis. However, it was found that individual anxiety has no effect on motivation.

Conclusion and recommendations. The research results provide evidence that $\mathrm{Z}$-generation has a high level of sociability. Because a serious pandemic such as COVID-19 has been shown to increase the socialization anxiety of the Z-generation more than their individual concerns. According to this conclusion, it can be said that the motivations of Z-generation individuals are negatively affected due to constraints in this period of time. Furthermore, concerns about socialization have been found to negatively affect both the intrinsic motivations and the extrinsic motivations of young people. This result is not surprising. Because even though $\mathrm{Z}$-generation youth are considered as a technology-oriented group, it is a reality that it is not possible to acquire the elements such as love, belonging and respect that are the most basic needs of human beings from social environments. It is also observed that individual anxiety levels did not have an impact on motivation. This result is an evidence that Z-generation youth care more about technological and social phenomena than individual and physical situations. These conclusions, along with these, are important in terms of joining the emphasis that Z-generation is a social generation, as well as showing that human sociality does not only occur through social media and smartphones. The resulting results show that the Z-generation youth need to be understood and actions and decisions should be taken accordingly.

Keywords: COVID-19, Anxiety, Generation Z, Intrinsic Motivation, Extrinsic Motivation

Öz: COVID-19 pandemisinin etkileri sağlık, ekonomi gibi alanlarda olduğu kadar insanı sosyal bir varlık olarak gören davranışsal alanlarda da söz konusudur. 65 yaş ve üzeri bireyler ile gençlerin bu dönemde yaşadıkları farklı süreçler ortaya çıkmıştır. Bu süreçte özellikle Z kuşağı olarak adlandırılan gençlerin "sosyal mesafe" de dahil olmak üzere birçok konuda bilinçli hareket etmesine ilişkin önlemler ve yaptırımlar söz konusudur. $\mathrm{Bu}$ dönemin gençlerin üzerinde nasıl bir etki yarattığı merak edilmektedir. Bu kapsamda araştırmanın amacı COVID-19 salgınının yarattığı kaygının Z kuşağının motivasyonu üzerindeki etkisini ortaya koymaktır. Bu amaçla çalışmanın örneklemini Kastamonu Üniversitesi’nin farklı bölümlerinde öğrenim gören 398 öğrenci oluşturmaktadır. Veriler anket yöntemiyle toplanmıştır. Ayrıca Kastamonu Üniversitesi Sosyal ve Beşeri Bilimler Araştırma ve Yayın Etik Kurulu'nun 30.06.2020 tarih ve 2020/2-8 nolu kararı ile etik kurul onayı alınarak çalışma gerçekleştirilmiştir. Hipotezler test edilirken doğrulayıcı faktör analizi, korelasyon analizi ve regresyon analizleri gerçekleştirilmiştir. Araştırma sonucunda COVID-19 salgını nedeniyle ortaya çıkan sosyalleşme kaygısının bireysel kaygıdan yüksek olduğu görülmüştür. İçsel motivasyonun ise dışsal motivasyondan düşük olduğu tespit edimiştir. Ayrıca Z kuşağının sosyalleşme kaygısının hem içsel hem de dışsal motivasyonu anlamlı ve olumsuz yönde etkilediği ortaya çıkmıştır. Fakat

Turkish Studies, 15(4) 
bireysel kaygının motivasyon üzerinde herhangi bir etkisinin olmadığı bulunmuştur. Çalışma COVID-19 pandemisi ile ilgili $Z$ kuşağı üzerinde yapılan ilk çalışmalardan olması nedeniyle yazına katkı sunmaktadır.

Anahtar Kelimeler: COVID-19, Kaygı, Z Kuşağı, İçsel Motivasyon, Dışsal Motivasyon

\section{Giriş}

Kaygı, psikoloji bilimini içinde barındıran tüm alanlarda sıklıkla araştııılan konulardan bir tanesidir. Kaygının ortaya çıkması için birçok neden söz konusudur. Bu nedenler bir madenci, akademisyen, sporcu ya da öğrenci için farklılaşabilmektedir. Fakat küreselleşmenin neden olduğu gelişmelerle birlikte kaygının nedenleri de çeşitlenmeye başlamıştır. Hatta küresel boyutta herkes için etkili olan yeni kaygı nedenleri de ortaya çıkmaya başlamıştır. Bunlardan bir tanesi de 2019 yılı Aralık ayında Çin'in Vuhan kentinde ortaya çıkan ve tüm dünyada etkili olan COVID-19 olarak adlandırılan pandemidir. COVID-19'un Dünya Sağlık Örgütü (DSÖ) tarafından küresel bir salgın olarak nitelendirilmesi ile birlikte toplumsal hayatta dünya genelinde bir farklılaşma ortaya çıkmaya başlamıştır (Sağlı Bakanlığı, 2020: 5). Uçak seferleri iptal edilmiş, futbol müsabakaları ertelenmişsiptal edilmiş, kongre ve sempozyumlar yapılamamış ya da uzaktan programlar vasıtasıyla gerçekleştirilmiş, yüz yüze eğitim-öğretime ara verilmiş, sokağa çıkma ile ilgi kısıtlamalar ortaya çıkmıştır. Bu yüzden toplumsal yaşama dair bu gelişmelerin ve değişimlerin sadece sağlık sektörü özelinde değerlendirilmesi yeterli değildir. Çünkü söz konusu salgın sosyal bir varlık olan insanı "sosyal mesafe" konusunda sınırlayan bir sonuç ortaya çıkarmaktadır.

$\mathrm{Bu}$ çerçevede yerli yazında sağlık sektörü dışında COVID-19 pandemisi ile ilgili yapılan çalışmaların pandeminin turizm sektörüne (Kıvılcım, 2020; Acar, 2020; Atay, 2020; Bahar \& Çelik İlal, 2020; Demir vd., 2020; Günay vd., 2020; İbiş, 2020) ve ekonomiye etkileri (Tosunoğlu ve Kasal, 2020; Şenol \& Zeren, 2020; Alpago \& Alpago, 2020; Arabacı \&Yücel, 2020) başta olmak üzere online ve uzaktan eğitim süreçlerine etkileri (Yamamoto \& Altun, 2020; Dikmen \& Bahçeci, 2020), havacıllk sektörüne etkileri (Akca, 2020; Macit \& Macit, 2020), gıda sektörüne etkileri (Şen, 2020), spor sektörüne etkileri (Aygün \& Ünal, 2020; Arısoy vd., 2020), tüketicilerin satın alma süreçlerine etkileri (Telli Danışmaz, 2020), konut sektörüne etkileri (Kayış, 2020), bankacılık sektörüne etkileri (Güler, 2020) gibi konulara odaklandığı görülmektedir. Bunun yanında pandemi ile ilgili bazı ölçek geliştirme çalışmalarının da (Biçer vd., 2020; Tekkurşun Demir vd. 2020; Arpacı vd. 2020) gerçekleştirildiği görülmektedir. Bu dönemde özellikle hem eğitim hem de sosyalleşme anlamında COVID-19 pandemisinden fazlasıyla etkilenen genç bireyler üzerine gerçekleştirilen çalışmaların (Yakar vd., 2020) sayısının çok az sayıda olduğu söylenebilir.

COVID-19 döneminde 65 yaş ve üzerini korumaya yönelik önlemler adına Z kuşağı olarak adlandırılan 2000 yılı sonrasında doğan gençlere (Kuran, 2013) bazı tedbirler uygulanmaktadır. Özellikle yaşları gereği sosyal ortamları fazlasıyla kullanan bu gençlerin sokağa çıkması noktasındaki kısıtlamalar önlemlerin başında gelmektedir. Ayrıca çok kısa bir zaman önce üniversitelerinde çok farklı bir ortamda eğitim ve öğrenimlerini sürdüren ve sosyalleşme süreçlerine devam eden bu gençlerin hem eğitim hem de sosyalleşme noktasında bir anda farklı bir sistem içerine girdikleri bir gerçekliktir. Türkiye nüfusunun yaklaşık yüzde 17'sini oluşturan (Tekin \& Zorkun, 2019: 123) ve ülkenin geleceğini oluşturan $Z$ kuşağı gençliliğinin böyle bir dönemde duydukları kaygıları ve bu kaygının ortaya çıkardığı etkileri ortaya koymak gerekmektedir. Çünkü geleceği şekillendirecek gençler ile ilgili alınacak her bir karar gelecekte toplumsal olarak büyük etkiler yaratabilecektir. $\mathrm{Bu}$ nedenle bu süreçte gençleri ve psikolojilerini çok iyi anlamak önem arz etmektedir. Bunlarla birlikte salgının etkilerinin sadece sağlık sektörü ve ekonomik bağlamda değil örgütsel davranış disiplini içerisinde yer alan ve insanın sosyal bir varlık olduğunu ortaya koyan davranışsal açısından da ele alınması gereklidir. 
$\mathrm{Bu}$ bağlamda çalışmada $\mathrm{Z}$ kuşağı içerinde yer alan üniversite öğrencilerinin COVID-19 kaygılarının motivasyon düzeylerini nasıl etkilediğinin ortaya konulması amaçlanmaktadır. Bu amaç çerçevesinde çalışmanın giriş bölümü takip eden ilk bölümünde literatür taraması çerçevesinde geliştirilen araştırma hipotezlerine yer verilmiştir. Ardından araştırmanın örneklemi, veri toplama araçları ve yöntemi ile değişkenlerin ölçümlenmesi ve analizine ilişkin araştırma tasarımına değinilmiştir. Sonrasında araştırma bulgularına yer verilerek sonuç ve önerileri ile çalışma sonlandırılmıştır.

\section{Literatür Taraması ve Hipotezler}

En genel anlamıyla kötü bir şey olacakmış düşüncesiyle ortaya çıkan ve sebebi bilinmeyen gerginlik duygusu olarak ifade edilen (TDK, 2020) kaygı ile ilgili yazında yapılan araştırmaların kaygının nedenleri, belirtileri, ortaya çıkardığı sonuçlara odaklandığı görülmektedir. Bununla birlikte kaygının belli düzeylerde olmasının yararlı olabileceğine ilişkin bir bakış açısı söz konusudur. Allwright vd. (1991) kaygının motive edici, uyarıcı ve koruyucu özelliklerinin olduğunu ifade etmektedir. Böylece kaygının insanı yaratıcı ve yapıcı davranışa yönlendirdiği iddia edilmektedir. Fakat bu yaratıcı ve yapıcı davranış kaygının orta düzeyde gerçekleşmesi ile söz konusu olabilecektir. Çünkü düşük ya da yüksek düzeyde kaygının olumlu davranışları engellemesi söz konusudur (Akgün, 2018). Yazında kaygının demografik değişkenler özellikle de yaş ile olan ilişkisini ele alan çalışmalar (Güngör, 2011; Akgün, 2018; Navruz, 2018; Beksaçi, 2019) görülebilmektedir. Fakat özellikle teknoloji çağı içerisine doğmuş Z kuşağının kaygı düzeylerini incelenmesi ben kuşağı olarak da adlandırılan bu gençlerin anlaşılmasına yararlı olabilir. Çünkü bilgi iletişim teknolojilerinin tam da ortasına doğan $\mathrm{Z}$ kuşağının teknolojide yaşanan gelişmelerle birlikte farkındalığı artmakta, diğer kuşaklar ile karşılaştırıldığında daha farklı becerilere sahip olduğu görülebilmektedir (Aydın Çetin \& Başol, 2014: 4). Z kuşağı teknolojinin içinde doğması sebebiyle birçok konuda uyum ve ilgisinin çok daha kolay olmasından dolayı (Tekin \& Zorkun, 2019) COVID19 dönemindeki bazı düzenlemelere de uyum ve ilgisinin nasıl olduğu merak edilmektedir. $\mathrm{Bu}$ nedenle COVID-19 salgınının ortaya çıkardığı bilinmezlik ile birlikte $Z$ kuşağı gençliğinin kaygı düzeylerinin durumu ve bu kaygını söz konusu kuşağın motivasyonunda yarattı̆̆ 1 etkiyi belirlemek gelecekle ilgili kararlarda yol gösterici olabilecektir. Bu kapsamda yerli ve yabancı yazında motivasyon ile kaygı arasındaki ilişkiyi ele alan bazı çalışmalara (Koruç, 2009; Yıldııım, 2011; Jain \& Sidhu, 2013; Yalçınsoy, 2017; Akpur, 2017; Müezzin \& Özata, 2019) rastlandığı görülmektedir.

Jain \& Sidhu (2013) Malezya'da eğitim fakültesinde öğrenim gören öğrenciler üzerine kayg1 ve motivasyon arasındaki ilişkiyi araştıran bir çalışma gerçekleştirmiş̧lerdir. Araştırma sonucunda kaygı ile motivasyon arasında negatif yönde anlamlı bir ilişki olduğunu tespit edilmiştir. Koruç (2009) gerçekleştirdiği çalışmada sporcu atletlerin yarışmadan önce yaşadıkları durumluk kaygılarının motivasyon boyutları ile ilişkisini ele almıştır. Araştırma sonucunda genç atletlerin yarışmadan önce durumluk kaygılarının motivasyon boyutları ile arasındaki ilişkilerin anlamlı olduğu görülmüştür. Yıldırım (2011) gerçekleştirdiği çalışmada içsel motivasyon ile kaygının ilişkisini ve söz konusu ilişkinin matematik başarısı üzerindeki etkisini ele almıştır. Çalışma sonucunda kaygı ve içsel motivasyonun akademik başarı üzerinde aracı rolü olduğunu tespit etmiştir. Ali \& Iqbal (2014) gerçekleştirdikleri çalışmada kaygı ile motivasyon arasındaki ilişkiyi ikinci bir dil öğrenmek isteyen öğrenciler üzerinde araştırmışlardır. Çalışma sonucunda iletişim ve sınav kaygısının motivasyonun çeşitli boyutları ile negatif yönlü ilişkisi olduğunu tespit etmişlerdir. Yalçınsoy (2017) gelecek kaygısının motivasyon üzerindeki etkisini ele aldığı çalışmada Dicle Üniversitesi öğrencileri üzerinde bir anket çalışması gerçekleştirmiştir. Araştırma sonuçları gelecek kaygısının öğrencilerin motivasyonunu pozitif ve anlamlı yönde etkilediğini ortaya koymaktadır. Akpur (2017) gerçekleştirdiği çalışmada erteleme, motivasyon, kaygı ve akademik başarının yordayıcı ve açılayıcı ilişkilerini ele almıştır. Araştırma sonuçları kaygının akademik başarı ile anlamlı bir iliş̧kisinin olmadığına işaret etmektedir. Ayrıca erteleme davranışının, motivasyonun ve kaygının akademik başarı ile arasındaki açıklayıcı ve yordayıcı ilişkiler örüntüsünü bir model ile 
sunmuştur. Navruz (2018) gerçekleştirdiği çalışmada belli takım sporları içerisinde yer alan lisede okuyan öğrencilerin çıktıkları karşılaşmalardan önce başarı motivasyonu ve sürekli kaygı ilişkisini belirlemek istemiştir. Araştırma sonucunda öğrencilerin spora özgü başarı motivasyonunun artmasının durumluk kaygıyı azaltı̆̆ı vurgulanmıştır. Ayrıca spora özgü başarı motivasyonunun artmasının sürekli kaygıyı azalttığı; durumluk kaygının artmasının ise sürekli kaygıyı arttırdığı tespit edilmiştir. Müezzin \& Özata (2019) yaptıkları çalışmada öğrencilerin Fen ve Teknoloji dersindeki motivasyonlarının kaygıları ile arasındaki ilişkiyi belirlemeye çalıştıkları çalışma sonucunda dersi öğrenme kaygısının motivasyon ile arasında düşük seviyede negatif ve anlamlı ilişkisini ortaya koymuşlardır.

Tüm bu çalışmalarla birlikte yazındaki çalışmaların daha çok belli olayları gerçekleştirme noktasında kaygı ile motivasyon arasında ilişkiyi ele aldığı görülmesine rağmen COVID-19 pandemisinin kaygı düzeyini ne derece etkilediğine ilişkin bir çalışmanın olmaması böyle bir kaygının motivasyon üzerindeki etkisi konusunda merak uyandırmaktadır. Ayrıca yapılan bazı çalışmalarda kaygının motivasyonu olumlu etkilediği işaret edilmesine karşın COVID-19 pandemisi birçok belirsizliği beraberinde getiren bir salgın olduğundan dolayı kontrolsüz kaygı yaratma ihtimali yüksektir ve bunun kişinin enerjisini tüketerek motivasyonunu düşürmesi beklenmektedir. $\mathrm{Bu}$ bağlamda Hipotez 1 ve Hipotez 2 geliştirilmiştir.

Hipotez $1\left(\mathrm{H}_{1}\right)$ : COVID-19 pandemisinin neden olduğu bireysel kaygı Z kuşağının motivasyonunu ( $\mathrm{H}_{1 \mathrm{a}}$ : içsel motivasyonunu; $\mathrm{H}_{1 \mathrm{~b}}$ : dişsal motivasyonunu) etkilemektedir.

Hipotez $2\left(\mathrm{H}_{2}\right)$ : COVID-19 pandemisinin neden olduğu sosyalleşme kaygısı $\mathrm{Z}$ kuşağının motivasyonunu ( $\mathrm{H}_{2 \mathrm{a}}$ : içsel motivasyonunu; $\mathrm{H}_{2 \mathrm{~b}}$ : dişsal motivasyonunu) etkilemektedir.

Tüm bu açıklamalar 1şığında oluşturulan araştırmanın kavramsal modeli Şekil 1'de görülebilmektedir.

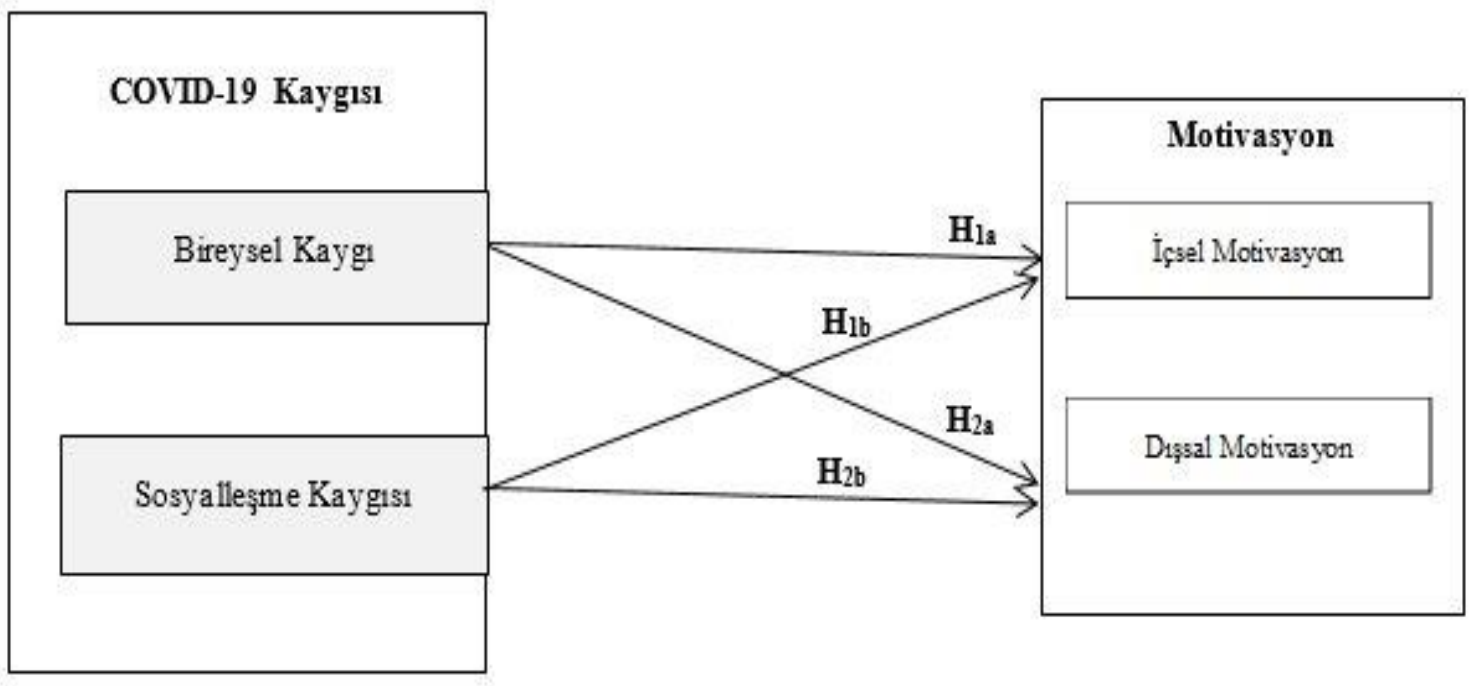

Şekil 1. Araşıırmanın Kavramsal Modeli

\section{Araştırmanın Yöntemi}

\section{Evren ve Örneklem}

Araştırmanın kapsamını Kastamonu Üniversitesi'nin farklı yüksekokul ve fakültelerinde öğrenim gören ve COVID-19 pandemisi nedeniyle 2019-2020 Bahar dönemine uzaktan eğitim ile devam eden $Z$ kuşağ içerinde yer alan öğrenciler oluşturmaktadır. Tüm birimler seçimde eşit şansa sahip olduklarından dolayı basit tesadüfi örnekleme yöntemi kullanılarak araştırmanın örneklemi 
seçilmiştir. Bu kapsamada e-posta ve sosyal mecralardan gönderilen soru formlarına dönüş yapan 398 adet Z kuşağı içerisinde yer alan üniversite öğrencisi örneklemi oluşturmaktadır. Örneklem hacmi belirlenirken güven düzeyi \% 95 (z tablo değeri 1.96), duyarlılık düzeyi ise $\% 5$ olarak alınmıştır. $\mathrm{Bu}$ bağlamda evren bilindiğinde aşağıdaki örneklem hesaplama formülü kullanılabilmektedir:

$\mathrm{n}=(\mathrm{z} 2) \mathrm{p} \mathrm{q} \mathrm{N} /(\mathrm{d} 2) \mathrm{N}+(\mathrm{z} 2) \mathrm{p} \mathrm{q}$

$\mathrm{N}$ : Evrendeki birim sayıs

n: Örneklemdeki birim sayısı

z: Belirli serbestlik derecesi ve saptanan yanılma düzeyinde t istatistiği

p: İncelenen olayın görülme olasılı̆g 1

q: p'nin tümleyeni (1-q)

d: Örneklem hatası

$\mathrm{n}=(1.962) 0.50 .517244 /(0.052) 17244+(1.962) 0.50 .5=376$

Yukarıda görüldüğü üzere $\% 5$ duyarlılık düzeyinde en az 376 adet soru formu toplanması gerekliliği söz konusudur. Çalışmada ise 398 adet soru formunun toplanarak analize dahil edilmesi ile $\% 95$ güven düzeyi ve $\% 5$ duyarlılık seviyesinde gerekli örneklem hacmine ulaşılmıştır. Yazıcıŏ̆lu ve Erdoğan (2004) belirtilen şartlar altında evren büyüklüğü ne olursa olsun 384 adet anketin evreni temsil ettiğini ifade etmektedir. Bu bağlamda çalışmanın örneklem büyüklüğü evreni temsil edecek büyüklüktedir.

\section{Araştırmanın Veri Toplama Yöntemi ve Araçları}

Araştırmada veri toplama aracı ankettir. Anket formu üç bölümden oluşmaktadır. İlk bölümde katılımcıların demografik özelliklerine yönelik tanımlayıcı sorulara yer verilmiştir. Bazı araştırmacılar (Kuran, 2013) Z kuşağını 2000 yılı ile birlikte doğanlar olarak nitelendirmiş olsa da Türkiye'de ilk internet bağlantısının 1993 tarihinde geldiği de düşünülerek Fox'un (2011) tanımlamasından hareket edilmiştir. Bu bağlamda soru formunun ilk bölümünde doğru kişilere ulaşılabilmesi için doğum tarihi olarak 1996 yılı baz alınmış ve doğum tarihi 01.01.1996 ve sonrası olanların anket devam etmeleri sağlanmıştır. İkinci bölümde COVID-19 kaysını ölçemeye yönelik sorular yer almıştır. Üçüncü bölümde gençlerin motivasyonunu ölçmeye yönelik sorulara yer verilmiştir.

COVID-19 salgınına ilişkin kaygı düzeylerini ölçümlemek için Tekkurşun vd. (2020) tarafından geliştirilen Sporcuların Yeni Tip Koronavirüse Yakalanma Kaygısı Ölçeğinden (SYTKYKÖ) yararlanılmıştır. COVID-19 dönemi ile geliştirilen ölçekte yer alan 16 soru bireysel kaygı ve sosyalleşme kaygısı olmak üzere iki boyuttan oluşmaktadır. Ölçekte yer alan tüm ifadeler örnekleme göre uyarlanarak kullanılmıştır. Ölçekte yer alan ifadeler 5'li Likert tipi sorulardan oluşmakta olup "1- Hiç Katılmıyorum", "2-Katılmıyorum”, "3-Kararsızım”, "4-Kat1lyorum”, "5Tamamen Katıllyorum" şeklinde sıralanarak derecelendirilmiştir.

Motivasyon düzeyini ölçümlemek için Tulunay Ateş ve İhtiyaroğlu (2019) tarafindan geliştirilen "Yetişkin Motivasyon Ölçeği" kullanılmıştır. Ölçekte içsel ve dışsal motivasyon olmak üzere iki boyut yer almaktadır. Ölçekte 21 adet soru yer almaktadır. Ölçekte yer alan tüm ifadeler orijinal ölçekte olduğu gibi kullanılmıştır. Ölçekte yer alan ifadeler "1-Kesinlikle Katılmıyorum", "Katılmıyorum", "3-Orta Derecede Kat1liyorum", "4-Kat1lıyorum" "5-Kesinlikle Kat1liyorum" şeklinde beşli Likert tipinde hazırlanmıştır. 


\section{Araştırmanın Değişkenleri ve Ölçüm Yöntemleri}

Araştırmanın amacı göz önüne alındığında araştırmanın bağımsız değişkeni COVID-19 kaygısı ve alt boyutlarıdır. Bağımlı değişkenler ise motivasyon ve motivasyonun alt boyutlarıdır. Araştırmada ele alınan değişkenlere ilişkin tanımlamalar, soru sayıları, ölçüm yöntemleri ve esinlenilen kaynaklar Tablo 1'de özetlenmektedir.

Tablo 1: Değişkenler ve Ölçümlenmesi

\begin{tabular}{|c|c|c|}
\hline Değişkenler & Değerlendirilmesi & Kaynak \\
\hline \multicolumn{3}{|c|}{ Demografik Özellikler } \\
\hline Cinsiyet & Kadın-Erkek & \\
\hline Sinif & Birinci - İkinci - Üçüncü - Dördüncü sınıf ve üzeri & \\
\hline Fakülte & $\begin{array}{c}\text { İktisadi ve İdari Bilimler-Mühendislik-Sağlık Bilimleri- } \\
\text { Fen Edebiyat-Orman-Turizm-Eğitim-İlahiyat-Güzel } \\
\text { Sanatlar-Veteriner-Sivil Havacılık-BESYO }\end{array}$ & \\
\hline $\begin{array}{c}\text { Birinci derece yakınınızda } \\
\text { COVID-19 vakası }\end{array}$ & Var-Yok & \\
\hline \multicolumn{3}{|c|}{ Bağımlı Değişken: Motivasyon } \\
\hline İçsel Motivasyon & \multirow{2}{*}{ 5’li Likert tipi 21 soru ile ölçülmüştür } & \multirow{2}{*}{$\begin{array}{l}\text { Tulunay Ateş \& } \\
\text { İhtiyaroğu (2019) }\end{array}$} \\
\hline Dişsal Motivasyon & & \\
\hline \multicolumn{3}{|c|}{ Bağımsız Değişken: COVID-19 Kaygısı } \\
\hline Bireysel Kayg1 & \multirow{2}{*}{ 5’li Likert tipi 16 soru ile ölçülmüştür } & \multirow{2}{*}{$\begin{array}{l}\text { Tekkurşun Demir } \\
\text { vd. (2020) }\end{array}$} \\
\hline Sosyalleşme Kaygısı & & \\
\hline
\end{tabular}

\section{Araştırmanın Bulguları}

\section{Demografik Bulgular}

Araştırmaya katılan Z kuşağı üniversite öğrencisi gençlerin 253 tanesi kadın iken 145 tanesi erkektir. Bu öğrencilerin çoğunluğu (165 kişi) birinci sınıf ve (115 kişi) ikinci sınıf öğrencilerinden oluşmaktadır. Fakülte dağılımına bakıldığında ise en çok katılımıının (175 kişi) İktisadi ve İdari Bilimler Fakültesi öğrencilerinden olduğu görülmektedir. Bu fakülteyi eğitim fakültesi (49 kişi) izlemektedir. Araştırmaya katılan öğrencilerin çok azının (7 kişi) birinci derecede yakının COVID19'a yakalandığı görülmektedir. Tanımlayıcı bulguların özeti Tablo 2'de özetlenmektedir. 
Tablo 2: Katılımcılara İlişkin Tanımlayıcı Bulgular

\begin{tabular}{|c|c|c|c|}
\hline Değişkenler & Gruplar & Sayı & Yüzde \\
\hline \multirow{2}{*}{ Cinsiyet } & Kadın & 253 & 63,6 \\
\hline & Erkek & 145 & 36,4 \\
\hline \multirow[t]{4}{*}{ Sinıf } & Birinci & 165 & 41,5 \\
\hline & İkinci & 115 & 28,9 \\
\hline & Üçüncü & 65 & 16,3 \\
\hline & Dördüncü ve üzeri & 53 & 13,3 \\
\hline \multirow{12}{*}{ Fakülte } & İktisadi ve İdari Bilimler & 175 & 44,0 \\
\hline & Mühendislik & 29 & 7,3 \\
\hline & Sağlık Bilimleri & 29 & 7,3 \\
\hline & Fen Edebiyat & 47 & 11,8 \\
\hline & Orman & 3 & 8 \\
\hline & Turizm & 37 & 9,3 \\
\hline & Eğitim & 49 & 12,3 \\
\hline & İlahiyat & 10 & 2,5 \\
\hline & Güzel Sanatlar & 8 & 2,0 \\
\hline & Veteriner & - & - \\
\hline & Sivil Havacilık & 3 & 8 \\
\hline & BESYO & 8 & 2,0 \\
\hline \multirow{2}{*}{$\begin{array}{l}\text { Birinci derece yakında } \\
\text { COVID-19 vakası }\end{array}$} & Var & 7 & 1,8 \\
\hline & Yok & 391 & 98,2 \\
\hline
\end{tabular}

\section{Doğrulayıcı Faktör Analiz Bulguları}

Araştırma hipotezlerinde yer alan değişkenlere analizler uygulanabilmesi için faktör analizlerinin gerçekleştirilmesi gerekmektedir. Ölçekler daha önceden kullanıldı̆̆ında gerçekleştirilen çalışmada kullanılan soruların orijinal faktör yapısına uygunluğunu ve bu uygunluğun derecesini denetleyen analiz (DFA) Doğrulayıcı Faktör Analizidir. Araştırmada kullanılan ölçekler daha önceki çalışmalardan elde edildiğinden dolayı motivasyon soruları ve COVID-19 kaygı sorularına DFA uygulanmıştır. COVID-19 faktör analizine geçilmeden ters kodlanan ikinci soru program aracıllı̆̆ ile düzeltilmiş ve analize geçilmiştir. Uygulanan faktör analizleri sonucunda COVID-19 kaygısının orijinal ölçekte olduğu gibi bireysel kaygı ve sosyalleşme kaygısı olmak üzere iki boyuta ayrıldığı tespit edilmiştir. COVID-19 ölçeğinden hiçbir soru çıkarılmamıştır. Ölçeğin toplam güvenirliği 0,906 ile oldukça yüksek seviyededir. Alt boyutlardan bireysel kaygının güvenirliği 0,929 ile oldukça yüksek seviyede iken sosyalleşme kaygısının güvenirliği de 0,879 ile yüksek seviyede bulunmuştur. COVID-19 ölçeğine ilişkin faktör analiz bulguları Şekil 2'de gösterilmiştir. 


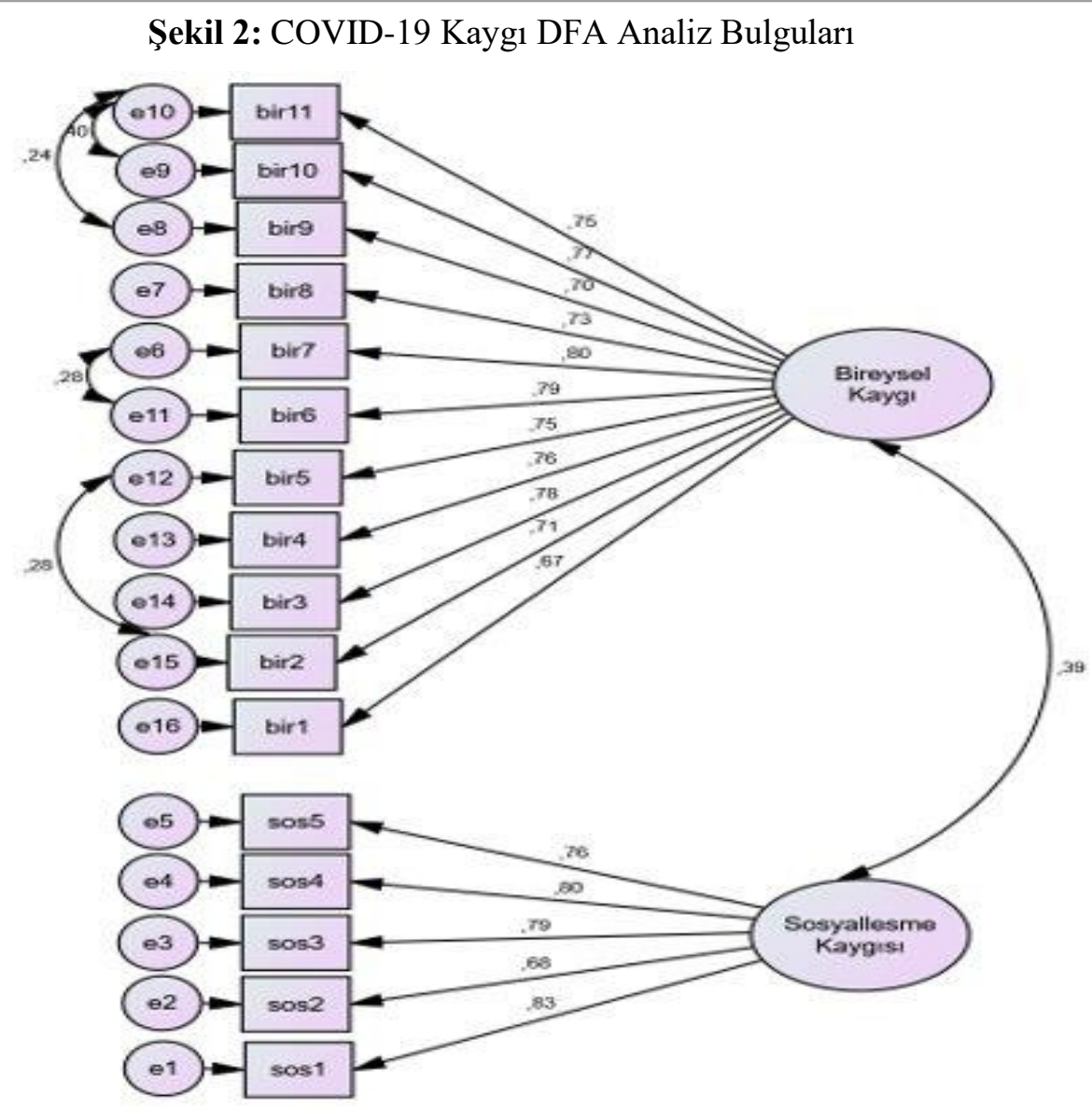

COVID-19 ölçeğine ilişkin uyum iyiliği değerlerine bakıldığında ise ölçeğin kabul edilebilir uyum değerlerine sahip olduğu belirlenmiştir. Uyum iyiliği değerleri ve kabul eilebilir sınırlar Tablo 3'te görülmektedir.

Tablo 3: COVID-19 Ölçeği Uyum İyiliği Değerleri

\begin{tabular}{cccc}
\hline $\begin{array}{c}\text { Uyum } \\
\text { Olçütleri }\end{array}$ & Normal Ölçüt & $\begin{array}{c}\text { Kabul Edilebilir } \\
\text { Ölçüt }\end{array}$ & $\begin{array}{c}\text { Elde Edilen Uyum } \\
\text { Ölçütleri }\end{array}$ \\
$\mathbf{X}^{2} / \mathbf{d f}$ & $\leq 3$ & $\leq 4-5$ & 3,244 \\
RMSEA & $\leq 0,05$ & $0,06-0,08$ & 0,075 \\
GFI & $\geq 0,95$ & $0,85-089$ & 0,902 \\
CFI & $\geq 0,95$ & $0,92-0,94$ & 0,944 \\
NFI & $\geq 0,95$ & $0,85-0,89$ & 0,922 \\
TLI & $\geq 0,90$ & $0,85-0,89$ & 0,932 \\
\hline
\end{tabular}

Motivasyon ölçeği için yapılan faktör analizi sonucunda ise orijinal ölçekten hiçbir soru çıkarılmamıştır. Ölçek içsel ve dışsal motivasyon olmak üzere iki boyuta ayrılmıştır. Ölçek boyutlarından içsel motivasyonun güvenirliği 0,942 ile oldukça yüksek çıkmıştır. Dışsal motivasyon ölçeğinin güvenirliği de 0,854 ile yüksek düzeyde tespit edilmiştir. Ölçeğin tamamının güvenirliği ise 0,928 ile oldukça yüksek seviyede çıkmıştır. Şekil 3 motivasyon ölçeğinin faktör analiz bulgularının özetini göstermektedir. 


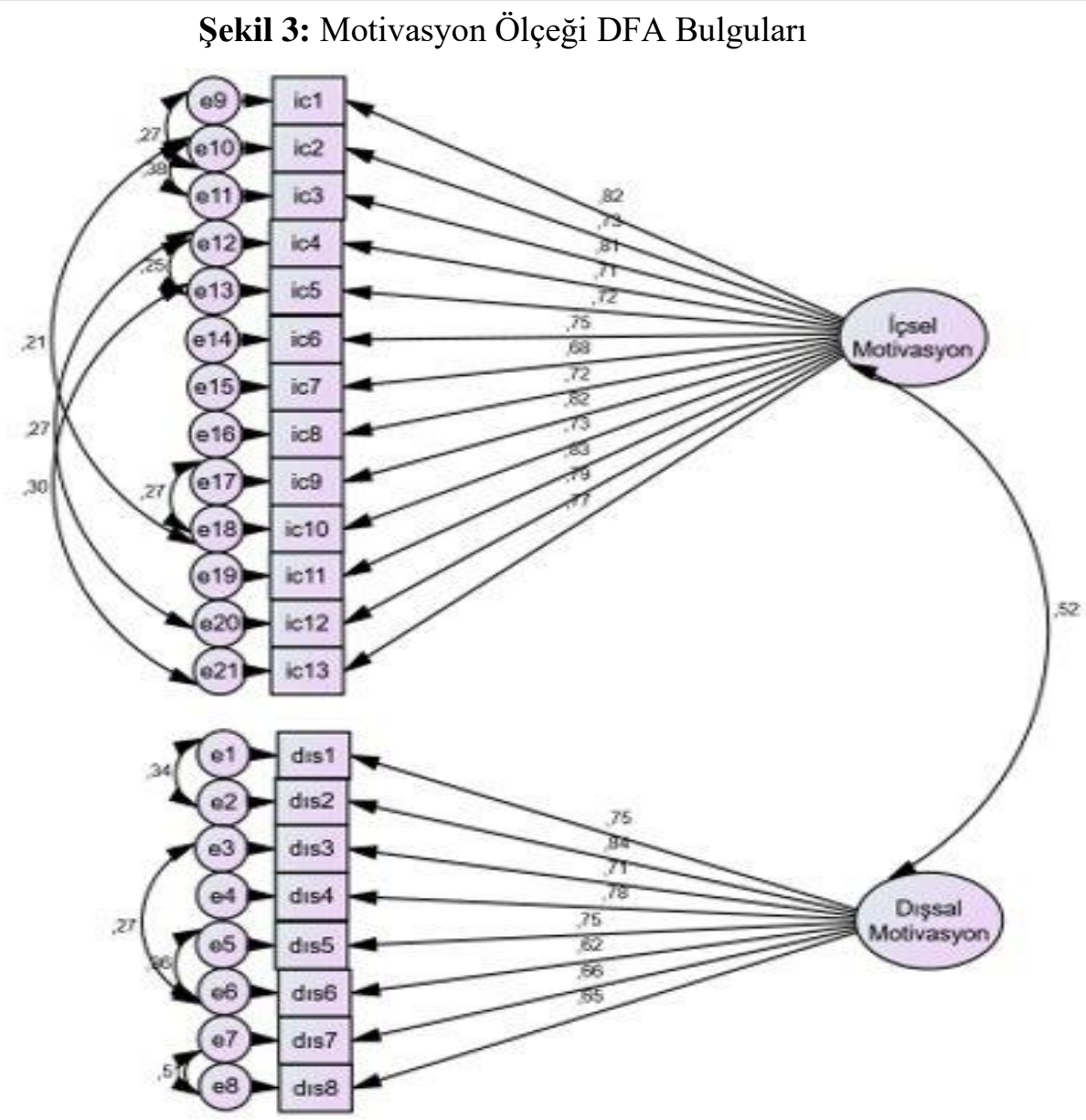

Motivasyon ölçeğine ilişkin uyum iyiliği değerlerine bakıldığında ise ölçeğin kabul edilebilir uyum değerlerine sahip olduğu belirlenmiştir. Uyum iyiliği değerleri ve kabul eilebilir sınırlar Tablo 4 'te görülmektedir.

Tablo 4: Motivasyon Ölçeği Uyum İyiliği Değerleri

\begin{tabular}{cccc}
\hline $\begin{array}{c}\text { Uyum } \\
\text { Ölçütleri }\end{array}$ & Normal Ölçüt & $\begin{array}{c}\text { Kabul Edilebilir } \\
\text { Ölçüt }\end{array}$ & $\begin{array}{c}\text { Elde Edilen Uyum } \\
\text { Ölçütleri }\end{array}$ \\
$\mathbf{X}^{2} / \mathbf{d f}$ & $\leq 3$ & $\leq 4-5$ & 3,448 \\
$\mathbf{R M S E A}$ & $\leq 0,05$ & $0,06-0,08$ & 0,079 \\
GFI & $\geq 0,90$ & $0,85-089$ & 0,874 \\
CFI & $\geq 0,95$ & $0,92-0,94$ & 0,928 \\
NFI & $\geq 0,90$ & $0,85-0,89$ & 0,903 \\
TLI & $\geq 0,90$ & $0,85-0,89$ & 0,915 \\
\hline
\end{tabular}

Tüm bunlarla birlikte güvenilir olmayan bir ölçeğin kullanışlı olmayacğından hareketlebirleşik güvenirliğe bakılmasında fayda vardır. Çünkü birleşik güvenirlik; sayıca birden fazla, heterojen fakat benzer ifadeleri içeren soruların genel güvenilirliğinin ölçülmesi için kullanılmaktadır (Raykov, 1998). Cronbach’s Alpha değerinin ise çok sayıdaki değişkenin varlığında yüksek değerleri gösterme eğiliminde olduğu ifade edilmektedir. Bu yüzden CR değeri Cronbach's Alpha değerine bir alternatifi veya kontrol aracı olarak kullanılabilir. CR değerinin 0.7'den büyük olması beklenmekteir. Ayrıca yakınsak geçerlilik için, ölçeğe ilişkin tüm CR değerlerinin AVE 
değerlerinden büyük olması beklenir. Bunun yanında AVE değerinin de 0,5 'ten büyük olması gerekmektedir (Yaşlığlu, 2017: 82). CR ve AVE değerleri hesağlanırken aşağıdaki formüller kullanılmıştır.
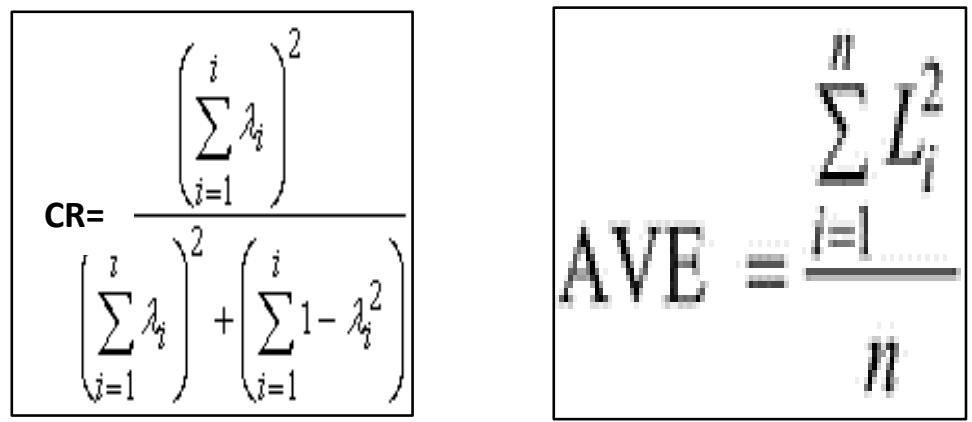

Her iki ölçek ve alt boyutlar için hesaplanan CR ve AVE değerleri Tablo 5'te özetlenmektedir.

Tablo 5: Ölçeklerin Birleşim Geçerliliği Bulguları

\begin{tabular}{ccccccc}
\hline Değer & $\begin{array}{c}\text { COVID19 } \\
\text { Kaygıs } \\
\text { Ölçeği }\end{array}$ & $\begin{array}{c}\text { Motivasyon } \\
\text { Ölçeği }\end{array}$ & $\begin{array}{c}\text { İçsel } \\
\text { Motivasyon }\end{array}$ & $\begin{array}{c}\text { Dişsal } \\
\text { Motivasyon }\end{array}$ & $\begin{array}{c}\text { Bireysel } \\
\text { Kaygı }\end{array}$ & $\begin{array}{c}\text { Sosyalleşme } \\
\text { Kaygıs }\end{array}$ \\
CR & 0,9548 & 0,5572 & 0,9470 & 0,8958 & 0,9325 & 0,8810 \\
AVE & 0,5702 & 0,9633 & 0,5799 & 0,5204 & 0,5576 & 0,5979 \\
CR>AVE & $>$ & $>$ & $>$ & $>$ & $>$ & $>$ \\
\hline
\end{tabular}

Tablo 5 incelendiğinde CR değerinin COVID-19 kaygısı ölçeği için 0,95; AVE değerinin ise 0,57 hesaplandığı görülmüştür. Motivasyon ölçeği için ise CR değerinin 0,96; AVE değerinin ise 0,55 hesaplandığ 1 görülmüştür. Ayıca tüm alt boyutlar içinde CR 070'ten büyük; AVE ise 0,50'de büyük çıkmıştır. Tüm alt boyutlarda da $\mathrm{CR}>\mathrm{AVE}$ değeridir. Bu bağlamda $\mathrm{CR}$ değerinin AVE değerinden büyük olması ölçeğin birleşim geçerliğini sağladığını da göstermektedir.

\section{Değişkenlerin Normallik Analiz Bulgular}

Hipotez testlerine geçilmeden önce araştırmaya katılanların COVID-19 kaygı düzeylerini ve motivasyon düzeylerine bakılmıştır. Ayrıca verilerin normalliğine ilişkin basıklık ve çarpıklık katsayıları incelenmiştir. Basıklık ve çarpıklık katsayılarının George ve Mallery'e (2010) göre ise \pm 2 aralığında yer alması kabul edilebilir bir durumdur. Analiz sonuçlarına bakıldığında değişkenlerin basıklık ve çarpıklık katsayılarına bakıldığında hiçbir değişkenin sınırlar dışında kalmaması nedeniyle verilerin normal dağıldığı varsayılarak parametrik testler gerçekleştirilmiştir. COVID-19 kaygısının yüksek düzeyde $(3,56)$ olduğu görülmektedir. COVID-19 kaygı boyutlarından sosyalleşme kaygısının ise $(3,79)$ bireysel kaygıdan $(3,33)$ daha fazla olduğu tespit edilmiştir. Katılımcıların motivasyona düzeylerine bakıldığında ise düşük seviyelerde $(2,80)$ olduğu bulunmuştur. Alt boyutlarda içsel motivasyonun $(2,73)$ dişsal motivasyondan daha düşük $(2,88)$ seviyede olduğu da analiz sonucunda görülebilmektedir. Değişkenlere ilişkin ortalamalar ile basıklık ve çarpıklık değer aralıkları Tablo 6' da görülmektedir. 
Tablo 6: Değişenlerin Ortlamaları ve Normallik Analiz Bulguları

\begin{tabular}{lccccc}
\hline Değişkenler & N & Ortalama & Stn. Sapma & Çarpıklık & Basıklık \\
\hline COVID-19 Kaygısı & 398 & 3,56 &, 5697 & $-1,386$ & 1,429 \\
\hline Bireysel Kaygı & 398 & 3,33 &, 5348 &,- 968 & 1,701 \\
\hline Sosyalleşme Kaygısı & 398 & 3,79 &, 8285 &,- 670 &,- 017 \\
\hline Motivasyon & 398 & 2,80 &, 5607 & 1,021 & 1,867 \\
\hline İçsel Motivasyon & 398 & 2,73 &, 5411 &, 617 &,- 034 \\
\hline Dışsal Motivasyon & 398 & 2,88 &, 7251 & 1,001 & 1,778 \\
\hline
\end{tabular}

\section{Korelasyon Analiz Bulgulart}

Yapılan analiz sonucu verilerin belirtilen değer aralığında çarpıklık ve basıklık değerlerine sahip olduğu anlaşıldıktan sonra korelasyon analizi gerçekleștirilmiştir. Yapılan korelasyon analizi sonucunda COVID-19 kaygısı ile motivasyon arasında $\left(\mathrm{r}=-, 372^{* *}\right)$, arasında negatif ve düşük düzeyde bir ilişkinin olduğu anlaşılmıştır. Ayrıca korelasyon analizi sonuçları bireysel kaygı ile motivasyon arasında $\left(\mathrm{r}=-, 163^{* *}\right)$ negatif ve düşük düzeyde bir ilişkiye işaret etmiş̧ir. Sosyal kaygı ise motivasyon ile $\left(\mathrm{r}=-, 407^{* *}\right)$ diğerlerinden daha yüksek ve negatif ilişki içerisindedir.

İlişkiler motivasyonun alt boyutları düzeyinde değerlendirildiğinde, COVID-19 kaygısı hem içsel motivasyon hem de dişsal motivasyon ile düşük düzeyde negatif anlamlı ilişki içerisindedir. Bireysel kaygı boyutu dışsal motivasyon ile negatif ilişki içerisinde iken içsel motivasyon ile anlamlı bir ilişkisi bulanamamıştır. Sosyalleşme kaygısının ise hem içsel hem de dışsal motivasyon ile anlamlı ve negatif yönde ilişkisi tespit edilmiştir. Analizlere ilişkin detaylı bilgiler Tablo 7'de yer almaktadir.

Tablo 7: Değişkenler Arası Korelaasyon Bulguları

\begin{tabular}{|c|c|c|c|c|c|c|}
\hline Değişken & COVKA & BİRKA & SOSKA & MOT & İÇMOT & DIŞMOT \\
\hline COVKA & 1 & & & & & \\
\hline BİRKA &, $737^{* *}$ & 1 & & & & \\
\hline SOSKA &, $900^{* * *}$ &, $368^{* *}$ & 1 & & & \\
\hline MOT &,$- 372^{* *}$ &,$- 163^{* *}$ &,$- 407^{* *}$ & 1 & & \\
\hline İÇMOT &,$- 277^{* *}$ &,- 068 &,$- 338^{* *}$ &, $844^{* *}$ & 1 & \\
\hline DIŞMOT &,$- 369^{* *}$ &,$- 201^{* *}$ &,$- 378^{* *}$ & $917^{\text {*** }}$ &, $559^{* *}$ & 1 \\
\hline \multicolumn{7}{|c|}{$\begin{array}{l}\text { COVKA: COVID-19 Kaygısı; BİRKA: Bireysel Kaygı; SOSKA: Sosyalleşme Kaygısı; MOT: Motivasyon; } \\
\text { IÇMOT: İscel Motivasyon; DIŞMOT: Dissal Motivasyon } \\
(* *) \% \text { 1, (*) \% } 5 \text { anlamlık düzeylerini ifade etmektedir. }\end{array}$} \\
\hline
\end{tabular}

\section{Hipotez Testlerine Illişkin Bulgular}

Korelasyon analizlerinin ardından hipotezlerin testi için regresyon analizleri gerçekleştirilmiştir. Hipotez 1 ile ilgili oluşturulan ilk modelde bağımlı değişken içsel motivasyon iken; ikinci modelde dışsal motivasyon bağımlı değişken olarak yer almıştır. Her iki modelde de bireysel kaygı ile sosyalleşme kaygısı bağımsız değişkenlerdir. Analiz bulguları Tablo 8'de özetlenmiştir. 
Tablo 8: Regreyon Analizi Bulguları

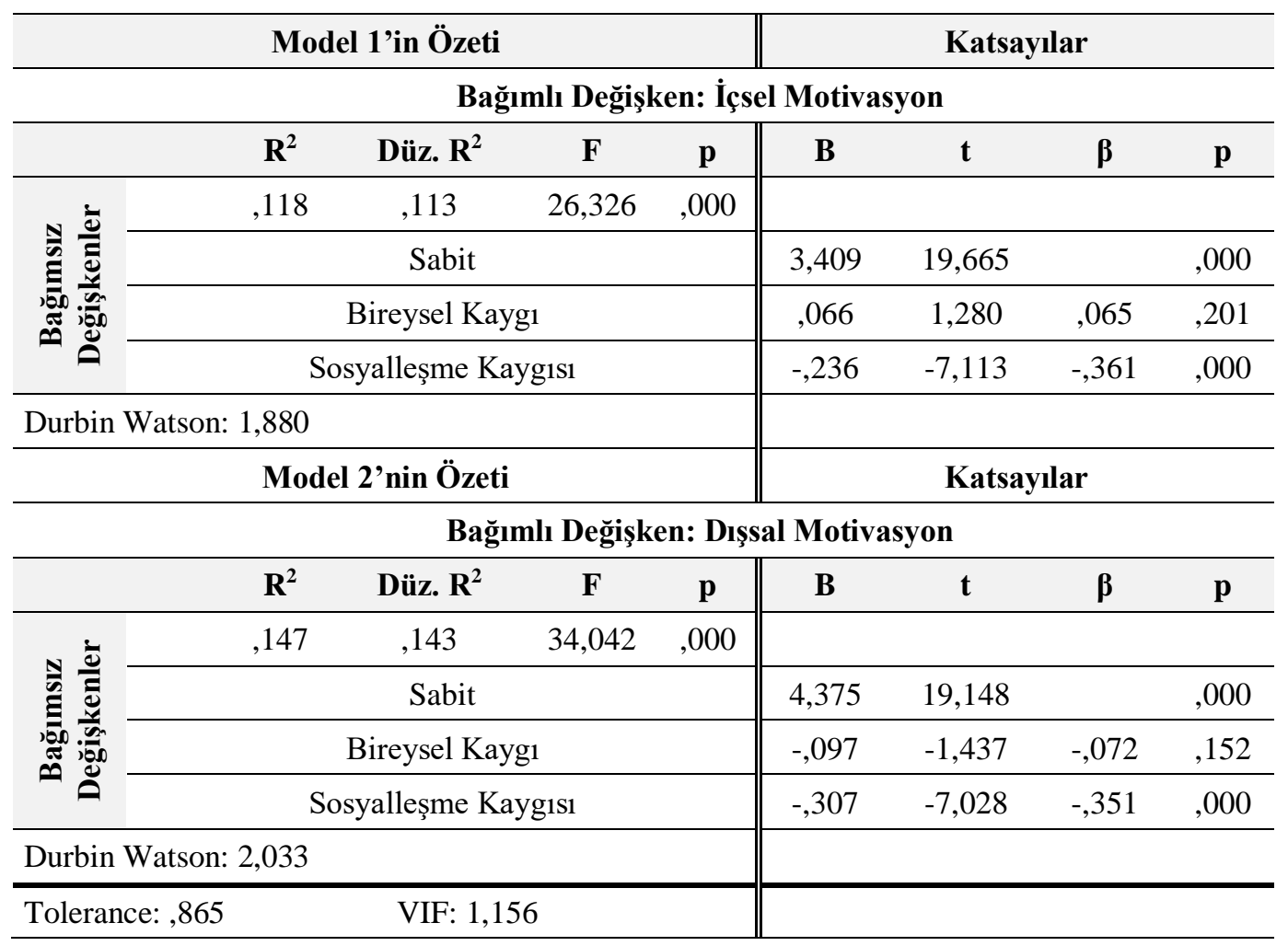

Tablo 8 incelendiğinde Model 1 bir bütün olarak anlamlıdır. Model katsayıları incelendiğinde COVID-19 pandemisini yarattığı bireysel kaygı düzeyinin içsel motivasyona anlamlı bir etkisi tespit edilememiştir. Fakat sosyalleşme kaygısının içsel motivasyon üzerinde \%1 düzeyinde anlamlı ve negatif etkisi $(\beta$ : -,361) bulunmuştur. Benzer şekilde Model 2 de bir bütün olarak anlamlıdır. Model katsayıları incelendiğinde COVID-19 pandemisini yarattığı bireysel kayg1 düzeyinin dışsal motivasyona anlamlı bir etki yaratmamaktadır. Fakat sosyalleşme kaygısının dışsal motivasyon üzerinde $\% 1$ düzeyinde anlamlı ve negatif etkisi ( $\beta$ : -,351)olduğu görülmüştür. $\mathrm{Bu}$ kapsamda geliştirilen araştırma hipotezlerinden $\mathrm{H}_{1 \mathrm{a}}$ ve $\mathrm{H}_{2 \mathrm{a}}$ reddedilirken; $\mathrm{H}_{1 \mathrm{~b}}$ ve $\mathrm{H}_{2 \mathrm{~b}}$ kabul edilmiştir. $\mathrm{Bu}$ kapsamda COVID 19 salgının Z kuşağının motivasyonunu kısmen etkilediği sonucuna varılmıştır.

\section{Sonuç ve Öneriler}

Araştırma sonuçları Z kuşağının sosyallik düzeyinin yüksek olduğuna kanıt sağlamaktadır. Çünkü COVID-19 gibi ciddi bir pandeminin Z kuşağının sosyalleşme kaygısını bireysel kaygılarından daha fazla arttırdığı görülmüştür. Z kuşağı bireylerin bu süreçte kısıtlamalar nedeniyle motivasyonlarının olumsuz etkilendiği de söylenebilir. Araştırmaya katılanların içsel motivasyon düzeylerinin dışsal motivasyondan daha düşük çıktığı da görülmektedir. Bu sonuç Z kuşağı üyeleri için dışsal ödüllerin daha düşük bir değere sahip olduğunu iddia eden görüşlerle (Twenge vd., 2010) benzerlik taşımaktadır.

Bunun yanında sosyalleşme ile ilgili kaygıların gençlerin hem içsel motivasyonlarını hem de dışsal motivasyonlarını olumsuz yönde etkilediği bulunmuştur. İçsel motivasyonun ise dişsal motivasyona göre daha fazla etkilendiği tespit edilmiştir. Bu sonuç şaşırtıcı değildir. Çünkü içsel motivasyon kaynaklarıla motive olabilen ve kendine son derece güvenen $Z$ kuşağı, geleceğini bireysel karar ve sorumluluklarla planlamayı tercih eden bir kuşaktır (Alp vd. 2019). Bununla birlikte her ne kadar Z kuşağı gençliği teknoloji odaklı bir grup olarak düşünülse de insanın en temel ihtiyacı 
olan sevgi, ait olma ve saygı gibi unsurların sosyal ortamlardan kazanılmasının çok mümkün olmadığı bir gerçekliktir. Ayrıca bireysel kaygı düzeylerinin motivasyon üzerinde bir etkisinin olmadığ 1 da görülmektedir. Bu sonuç $\mathrm{Z}$ kuşağı gençliğinin bireysel ve fiziksel durumdan ziyade teknolojik ve sosyal olguları daha çok önemsediğine bir kanıt olabilir. Bunlarla birlikte ortaya çıan bu sonuçlar Z kuşağının sosyal bir jenerasyon olduğu vurgusuna katılmanın yanında insanın sosyalliğinin sadece sosyal mecralar ve akıllı telefonlarla gerçekleşmediğini göstermesi açısından önemlidir. Ortaya çıkan sonuçlar Z kuşağı gençliğinin anlaşılması ve alınacak kararlarda buna göre hareket edilmesi gerektiğini göstermektedir.

Özellikle sağlık alanında ve ekonomik sonuçları itibariyle ele alınan COVID-19 pandemisinin hem sosyolojik ve psikolojik etkilerinin hem de örgütlerde çalışan bireylerin örgütsel davranışları üzerindeki etkilerinin ele alınması, böyle durumlarda alınacak önlemlerin çeşitlendirilmesi için önem arz etmektedir. Z kuşağı olarak adlandırılan gençlerle birlikte çalışma ortamlarındaki bireyler üzerine yapılacak çalışmalar bu konularda geleceğe 1şık tutabilecektir. Çalışma COVID-19 pandemisini Z kuşağı üzerinde yarattığı etkileri ele alan ilk çalışmalardan olması nedeniyle yazına katkı sağlamaktadır. Ayrıca gelecekte pandeminin yarattığı kaygı ve fobinin iş tatmini, örgütsel bağlılık, vatandaşlık davranışı gibi örgütsel davranış literatüründe sıklıkla araştırılan konularla ilişkisi incelenebilir.

Etik Onay Belgesi ve Anket Linki: Bu çalışmanın verileri Google Formlar aracılığı ile oluşturulan anket yardımıyla elde edilmiş olup soru formuna aşağıda yer alan linkten ulaşılabilmektedir. Anket formlarının kullanımı için ölçekleri ilk oluşturan bilim insanlarından e-posta gönderilerek izinleri alınmıştır. Ayrıca çalışmada kullanılacak anket formu için Kastamonu Üniversitesi Sosyal ve Beşeri Bilimler Araştırma ve Yyain Etik Kurulu'nun 30.06.2020 tarih ve 2020/2-8 nolu kararı ile etik kurul izni de alınarak çalışma gerçekleştirilmiştir.

https://docs.google.com/forms/d/1skowDmAW3tyDfEwzLjBHIpO9W9I37e5myjWOqiLOag8/edit

\section{Kaynakça}

Acar, Y. (2020). Yeni koronavirüs (COVID-19) salgını ve turizm faaliyetlerine etkisi. Güncel Turizm Araştırmaları Dergisi, 4(1), 7-21. https://doi.org/10.32572/guntad.703410

Akca, M. (2020). COVID-19'un havac1lık sektörüne etkisi. Avrasya Sosyal ve Ekonomi Araştırmaları Dergisi, 7(4), 45-64.

Akgün, S. (2018). İç iletişsim sürecinde kaygı düzeylerinin öğrenci başarısı üzerine etkisi (Üniversite ögrencileri üzerine uygulamalı çalışma). Selçuk Üniversitesi Sosyal Bilimler Enstitüsü.

Akpur, U. (2017). Predictive and explanatory relationship model between procrastination, motivation, anxiety and academic achievement. Eurasian Journal of Educational Research, $69,221-240$.

Ali, Q. M. \& Iqbal, M. N. (2014). Relationship of anxiety and motivation in learning english of secondary school student in developing country. Journal of Institute of Social Science, 2835 .

Alp, G. T., Tuncer, A. D., Sulaiman, S. A. B. \& Güngör, A. (2019). Çalışma hayatında Y ve Z kuşağının motivasyonel farklılıklarl. In Proceedings on 2nd International Conference on Technology and Science.

Alpago, H. \& Alpago, D. (2020). Koronavirüs salgınının sosyoekonomik sonuçları. IBAD Sosyal Bilimler Dergisi, (8): 99-114. https://doi.org/10.21733/ibad.716444 
Allwright, R., Allwright, D. \& Bailey, K. M. (1991). Focus on the language classroom: An introduction to classroom research for language teachers. Cambridge University Press.

Arabac1, H. \& Yücel, D. (2020) Pandeminin Türkiye ekonomisine etkileri ve türkiye merkez bankas1 tarafından finansal istikranı sağlamak amacıyla alınan önlemler. Sosyal Bilimler Araştırma Dergisi, 9(2), 91-98.

Arısoy, A., Pepe, O. \& Karaoğlu, B. (2020) COVİD 19 sürecinde futbola dönüş öncesi futbolcuların durumluk kaygı düzeyleri ile psikolojik performansları arasındaki ilişki belirlenmesi: Isparta örneği. Yalvaç Akademi Dergisi, 5(1), 55-63.

Arpac1, I., Karataş, K. \& Baloğlu, M. (2020). The development and initial tests for the psychometric properties of the COVID-19 Phobia Scale (C19P-S). Personality and Individual Differences, $164,1-6$.

Atay, L. (2020). KOVID-19 salgını ve turizme etkileri. Seyahat ve Otel İsletmeciliği Dergisi, 17(1), $168-172$.

Aydın Çetin, G. \& Başol, O. (2014). X ve Y: çalışma anlamında bir değişme var mı?. Electronic Journal of Vocational Colleges, 4, 1-15.

Aygün, M. \& Ünal, M. (2020). COVID-19 pandemisinin buz hokeyi sporuna etkisi. Anadolu Kliniği Tip Bilimleri Dergisi, 25(Supplement 1), 195-203.

Bahar, O. \& İlal Çelik, N. (2020). Coronavirüsün (COVID-19) turizm sektörü üzerindeki ekonomik etkileri. International Journal of Social Sciences and Education Research, 6(1), 108-122. https://doi.org/10.24289/ijsser.728121

Beksaçi, I. (2019). Üniversite ögrencilerinde yaşam doyumu ile depresyon ve kaygı düzeyleri arasındaki ilişki. Ondokuz Mayıs Üniversitesi Eğitim Bilimleri Enstitüsü.

Biçer, İ., Çakmak, C., Demir, H. \& Kurt, M. E. (2020). Koronavirüs anksiyete ölçeği kısa formu: Türkçe geçerlik ve güvenirlik çalışması. Anadolu Kliniği Tıp Bilimleri Dergisi, 25(Supplement 1), 216-225.

Demir, M., Günaydın, Y. \& Demir, Ş. Ş. (2020). Koronavirüs (COVID-19) salgınının Türkiye'de turizm üzerindeki öncülleri, etkileri ve sonuçlarının değerlendirilmesi1. International Journal of Social Sciences and Education Research, 6(1), 80-107. https://doi.org/10.24289/ijsser.734263

Dikmen, S. \& Bahçeci, F. (2020). COVID-19 pandemisi sürecinde yükseköğretim kurumlarının uzaktan eğitime yönelik stratejileri: Fırat üniversitesi örneği. Turkish Journal of Educational Studies, 7 (2), 78-98.

Fox, A. (2011). Mixing it up. HRMagazine, May-2011, pp. 22-27. Retrieved from https://www.shrm.org/hr-today/news/hr-magazine/pages/0511fox.aspx.

George, D. \& Mallery, P. (2010). SPSS for Windows step by step. A simple study guide and reference. MA: Pearson Education, Inc.

Güler, H. N. (2020). Koronavirüsü (COVID-19) günlerinde bankalara iletilen müşteri itiraz ve şikayetlerinin incelenmesi. Avrasya Sosyal ve Ekonomi Araştırmaları Dergisi, 7(4), 85-99.

Günay, F., Bayraktaroğlu, E. \& Özkul, K. (2020). Assessing the short-term 1mpacts of COVID-19 pandemic on foreign visitor's demand for turkey: a scenario analysis. Journal of Ekonomi, $2(2), 80-85$.

Güngör, T. (2011). Selçuk üniversitesi resim-iş eğitimi anabilim dalı ögrencilerinin kaygı ve yaşam doyumu düzeyleri. Selçuk Üniversitesi Eğitim Bilimleri Enstitüsü. 
İbiş, S. (2020). COVID-19 salgınının seyahat acentaları üzerine etkisi. Safran Kültür ve Turizm Araştırmaları Dergisi, 3(1), 85-98.

Jain, Y. \& Sidhu, G. K. (2013). Relationship between anxiety, attitude and motivation of tertiary students in learning English as a second language. Procedia-Social and Behavioral Sciences, $90,114-123$.

Kayış, F. (2020). Koronavirüs (COVID-19) salgınının konut ve çatılı işyerleri kiralarına etkileri üzerine düşünceler. Avrasya Sosyal ve Ekonomi Araştırmaları Dergisi, 7(4), 65-84.

Kıvılcım, B. (2020). COVID-19 (yeni koronavirüs) salgınının turizm sektörüne muhtemel etkileri. Uluslararası Batı Karadeniz Sosyal ve Beşeri Bilimler Dergisi, 4(1), 17-27. https://doi.org/10.46452/baksoder.727208

Koruç, P. B. (2009). Genç atletlerin yarışma öncesi durumluk kaygı düzeyleri ile motivasyon boyutları ve hedef yönelimleri arasındaki ilişki. Spor Hekimliği Dergisi, 44(2), 61-69.

Kuran, E. (2013). Yaşasın Y kuşağı. (Ropörtaj Yapan: A. Arman), http://www.hurriyet.com.tr/yasasin-y-kusagi-23465715.

Macit, A. \& Macit, D. (2020). Türk sivil havacılık sektöründe COVID-19 pandemisinin yönetimi. Avrasya Sosyal ve Ekonomi Araştırmaları Dergisi, 7(4), 100-116.

Müezzin, E. E. \& Özata, B. Ç. (2019). Ortaöğretim öğrencilerinde fen öğrenmeye yönelik kaygı ve motivasyon ilişkisi. Kıbrıs Türk Psikiyatri ve Psikoloji Dergisi, 1(1), 14-21.

Navruz, A. (2018). Seçili takım sporlarında mücadele eden lise ögrrencilerinin müsabaka öncesi durumluk ve sürekli kaygı düzeylerinin motivasyon düzeylerine olan etkisinin incelenmesi (Ankara ili ölçekli). Süleyman Demirel Üniversitesi Sağlı Bilimleri Enstitüsü.

Raykov, T. (1998). Coefficient alpha and composite reliability with interrelated nonhomogeneous items. Applied Psychological Measurement, 22(4), 375-385.

Şen, M. A. (2020). Koronavirüs (COVID-19) salgınının türkiye'deki yemek firmalarında oluşturduğu etkinin belirlenmesi üzerine bir araştırma. Afet ve Risk Dergisi, 3(1), 89-100. https://doi.org/10.35341/afet.717513

Şenol, A. \& Zeren, F. (2020). Coronavirus (COVID-19) and stock markets: the effects of the pandemic on the global economy. Avrasya Sosyal ve Ekonomi Araştırmaları Dergisi, 7(4), $1-16$.

T.C. Sağlık Bakanlığı (2020). COVID-19 (SARS-CoV-2 enfeksiyonu) genel bilgiler, epidemioloji ve tanı. Bilimsel Danışma Kurulu Çalışması, Ankara.

TDK (2020). Türk dil kurumu sözlükleri. https://sozluk.gov.tr/

Tekin, E. \& Zorkun, M. (2019). E-ticaret algısının Y ve Z kuşaklarının girişimcilik eğilimleri üzerindeki etkisi: kastamonu üniversitesi örneği, Gençlik Araştırmaları Dergisi, 7(18), 117 147.

Tekkurşun Demir, G., Cicioğlu, H. İ. \& İlhan, E. L. (2020). Anxiety of catching the novel coronavirus (COVID-19scale (ACNCS): Validity and reliability study. Journal of Human Sciences, $17(2), 458-468$.

Telli Danışmaz, A. (2020). COVID-19 salgınının tüketicilerin online alışveriş tercihine etkisi. Social Sciences Research Journal, 9(2), 83-90. 
Tosunoğlu, Ş. \& Kasal, S. (2020). Yeni koronavirüs (COVID-19) salgını ve sağlıklı küresel ekonomi için politika uygulamaları: IMF'nin rolü. Anadolu Üniversitesi İktisat Fakültesi Dergisi, 2(1), $35-49$.

Tulunay Ateş, A. \& İhtiyaroğlu, N. (2019). Yetişkin motivasyon ölçeği: bir ölçek geliştirme çalışması. Kastamonu Education Journal, 27(2), 611-620.

Twenge, J. M., Campbell S. M., Hoffman B. J. \& Lance C. (2010). Generational Differences in Work Values: Leisure and Extrinsic Values Increasing, Social and Intrinsic Values Decreasing. Journal of Management, 36(5), 1117-1142.

Yakar, B., Kaygusuz, T. Ö., Pirinçci, E., Önalan, E. \& Ertekin, Y. H. (2020). Knowledge, attitude and anxiety of medical students about the current COVID-19 outbreak in Turkey. Family Practice and Palliative Care, 5(2), 36-44.

Yalçınsoy, A. (2017). Yaşam doyumu, kaygı ve motivasyon ilişkisi ile ilgili üniversite gençliğine yönelik bir araştırma: Dicle üniversitesi örneği. Kesit Akademi Dergisi, 3(10), 422-434.

Yamamoto, G. \& Altun, D. (2020). Coronavirüs ve çevrimiçi (online) eğitimin önlenemeyen yükselişi. Üniversite Araştırmaları Dergisi, 3(1), 25-34.

Yaşlığlu, M. M. (2017). Sosyal bilimlerde faktör analizi ve geçerlilik: Keşfedici ve doğrulayıcı faktör analizlerinin kullanılması. Istanbul Üniversitesi Isletme Fakültesi Dergisi, 46(Special Issue), 74-85.

Yazıcıoğlu, Y. \& Erdoğan, S. (2004). SPSS uygulamalı bilimsel araştırma yöntemleri. Detay Yayıncilik, Ankara.

Yıldırım, S. (2011). Öz-yeterlik, içe yönelik motivasyon, kaygı ve matematik başarısı: Türkiye, Japonya ve Finlandiya'dan Bulgular. Necatibey Eğitim Fakültesi Elektronik Fen ve Matematik Eğitimi Dergisi, 5(1), 277-291. 